\title{
MODERN REQUIREMENTS TO THE STATE POLICY IN THE SPHERE OF ENVIRONMENTAL PROTECTION AND CHILDREN'S HEALIT: EXPERIENCE AND RECOMMENDATIONS OF THE WORID HEALTH ORGANIZATION
}

Koblianska A.V., Skliarenko K.A.

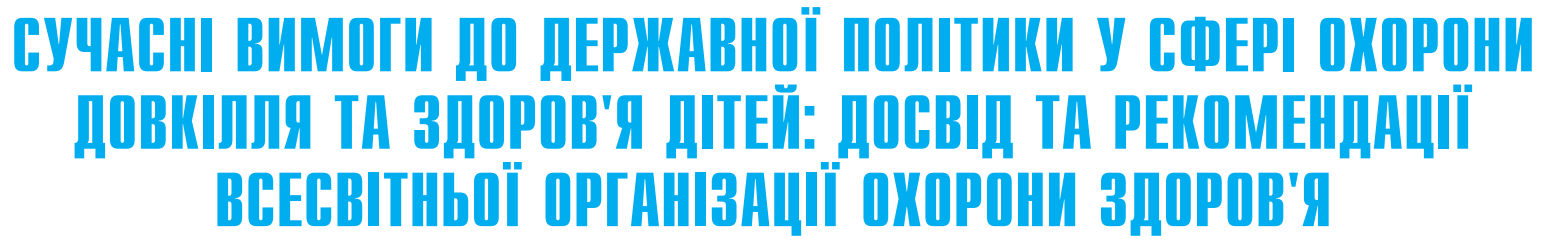

днією з найгостріших соціальних проблем в Україні $\epsilon$ стан здоров'я дітей. Незадовільний стан здоров'я у дитячому віці призводить до порушень здоров'я протягом усього життя людини, що створює соціальні та фінансові проблеми, негативно впливає на рівень соціально-економічного розвитку країни [8].

Україна як член міжнародного співтовариства бере участь у діяльності зі створення сприятливого для дітей середовища, в якому гідний розвиток і захист їхніх прав забезпечується з дотриманням принципів демократії, рівності, миру, соціальної справедливості, 3 урахуванням моральних засад та традиційних цінностей українського суспільства, спрямованих на зміцнення сім'ї та морального здоров'я дітей [13].

Мета роботи - проаналізувати міжнародний досвід, рекомендації

СОВРЕМЕННЫЕ ТРЕБОВАНИЯ К ГОСУДАРСТВЕННОЙ ПОЛИТИКЕ В СФЕРЕ ОХРАНЫ ОКРУЖАЮЩЕЙ СРЕДЫ И ЗДОРОВЬЯ ДЕТЕЙ: ОПЫТ И РЕКОМЕНДАЦИИ ВСЕМИРНОЙ ОРГАНИЗАЦИИ ЗДРАВООХРАНЕНИЯ

Коблянская А.В., Скляренко К.А.

ГУ "Институт общественного здоровья им. А.Н. Марзеева НАМН Украины", г. Киев

Цель работы - проанализировать международный опыт, рекомендации Всемирной Организации Здравоохранения для определения основных требований в формировании и реализации политики в рамках национальных программ системы окружающей среды, здоровья детей и подростков. Уровень общественного здоровья и состояние системы здравоохранения зависят от реальных социально-экономических процессов, происходящих в государстве. Прежде всего стратегия отрасли базируется на демографической ситуации, основных показателях здоровья населения с учетом факторов риска окружающей среды. По данным ВОЗ, влияние загрязненной окружающей среды на здоровье человека до сих пор является основной причиной смертности и страданий по всей Европе, особенно для детей. Дети как наиболее уязвимая часть общества чрезвычайно чувствительны к экологическим угрозам.

Учитывая европейский вектор развития, будущая система здравоохранения в Украине должна быть согласована с европейскими принципами, что предполагает замещение данной модели системы здравоохранения современными мировыми схемами, практиками и опытом, исходя из того, что дети и подростки являются одним из приоритетов государственной политики.

Ключевые слова: система здравоохранения, охрана окружающей среды, здоровье детей и подростков, Европейская стратегия, государственная политика, международный опыт.

Всесвітньої Організації Охорони Здоров'я, визначити основні вимоги при формуванні та реалізації політики у загальнодержавних програмах системи охорони довкілля та здоров'я дітей та підлітків.

Матеріали та методи. Проведено системний аналіз законодавчих документів і науково-методичних матеріалів В0O3, а також аналіз виконання державних програм України у галузі охорони здоров'я дітей та підлітків.

Результати. На формування здоров'я громадян України, як і більшості країн Європейського регіону, наприкінці $X X$ - початку XXI століття впливає ряд хронічних неінфекційних захворювань (НIЗ): хвороби системи кровообігу, злоякісні новоутворення, обструктивні захворювання легень, цукровий діабет, соціально-небезпечні хвороби та інше $[2,4]$.

2000 року Всесвітня Організація Охорони Здоров'я (ВООЗ) опублікувала Глобальну стратегію запобігання НІЗ і закликала усі держави розробити власні національні. Для досягнення успіху в їх розробці ВООЗ посилається на досвід прийнятої нею інтегрованої профілактики неінфекційних захворювань (CINDI) з використанням програмного підходу до регулювання впливу провідних нозологічних форм на стан здоров'я $[1,4]$.

Серед причин подібної ситуації з НІЗ у світі відзначаються насамперед так звані фактори ризику, а саме: вживання тютюну, зловживання алкоголем, нездоровий режим харчування і недостатня фізична активність. Негативний безпосередній вплив на рівні поширеності НІЗ мають такі соціальні фактори, як якість життя людини, нерівний розподіл багатства, брак освіти, стрімка урбанізація і старіння населення, а також соціально-економічні, гендерні, політичні, поведінкові та екологічні детермінанти здоров'я $[1,3]$.

Стан здоров'я дітей в Україні $€$ незадовільним у зв'язку з тенденцією до зростання захворюваності, поширеності хвороб та інвалідності. Процес депопуляції, що

() Коблянська А.В., Скляренко К.А. СТАТТЯ, 2016. 
MODERN REQUIREMENTS TO THE STATE POLICY IN THE SPHERE OF ENVIRONMENTAL

PROTECTION AND CHILDREN'S HEALTH: EXPERIENCE AND RECOMMENDATIONS OF THE WORLD HEALTH ORGANIZATION Koblianska A.V., Skliarenko K.A.

State Institution "O.M. Marzeyev Institute for Public Health of the National Academy of Medical Sciences of Ukraine", Kyiv

We analyzed the international experience, the recommendations of the World Health

Organization and identified the basic requirements at the development and implementation of the policy within the framework of the national programs on the environmental protection and children's and adolescents' health system. A level of public health and health services' state depend on the real socio-economic processes in the state. First of all, a sector strategy is based on the demographic situation, the main indicators of the health of the population taking into account the environmental risk factors. According to the data of the WHO, the impact of the contaminated environment on a human health is still a leading reason of death and sufferings throughout Europe, especially for children. Children as the most vulnerable part of society are extremely sensitive to the environmental threats. Allowing for the European vector of development, the future health services' system in Ukraine must be agreed with the European principles, it presupposes a replacement of the given model of health services by the modern world schemes, practices, and experiences, taking into account that children and youth are the priorities of state policy.

Keywords: health services, environmental protection, children's and adolescents' health, the European strategy, state policy, international experience. спостерігається в Україні починаючи з 1990 року, набув характеру демографічної кризи, в умовах якої збереження життя і здоров'я кожної дитини набирає надзвичайно важливого загальнодержавного значення [8]. Україна, підписавши у складі 189 країн світу 2000 року Декларацію тисячоліття Організації Об'єднаних Націй $(\mathrm{OOH})$, що декларує боротьбу з бідністю і розвиток людини як основу для досягнення стійкого соціального та економічного розвитку, зобов'язалася досягти до 2015 року зниження смертності дітей віком до 5 років на дві третини порівняно з 1990 роком [6]. Програмним для країн світу став також підсумковий документ спеціальної сесії в інтересах дітей Генеральної Асамблеї ООН у 2002 році "Світ, сприятливий для дітей", яким прийнято план дій щодо створення світу, сприятливого для дітей, і визначено завдання з забезпечення права кожної дитини на життя та охорону здоров'я [8].

Україна взяла на себе ряд зобов'язань 3 покращання добробуту дітей. Кабінет Міністрів України 10 травня 2002 року підписав документ "Світ, сприятливий для дітей", в якому визначено чотири пріоритетні напрями діяльності: пропагування здорового способу життя; забезпечення можливості здобувати високоякісну освіту; захист дітей від жорстокого поводження, насильства та експлуатації; боротьба 3 ВІЛ/СНІДом, а також передбачено глобальний план дій, орієнтований на розвиток і захист прав та інтересів підростаючого покоління, і завдання, які світова спільнота має виконувати для дітей та разом з дітьми [13].

За даними ВООЗ, одна із трьох смертей серед дітей в Європі через забруднене довкілля. Смертність через екологічні фак- тори на 34\% вища у дітей та підлітків до 19 років. Саме тому діти та їхнє майбутнє є темою для обговорення та дій щодо покращання довкілля та здоров'я. Так, 1989 року у Франкфурті відбулася перша зустріч міністрів довкілля та здоров'я, яка започаткувала серію конференцій, що відбуваються кожні п'ять років. Наступними стали Гельсінкі (1994), Лондон (1999), Будапешт (2004), Парма (2010). Шоста Європейська міністерська конференція з довкілля та охорони здоров'я відбудеться 2016 року. Саме на Четвертій конференції на рівні міністрів 3 довкілля та охорони здоров'я "Майбутне для наших дітей" (Будапешт, Угорщина) 23-25 червня 2004 р. було прийнято "План дій для довкілля та здоров'я дітей Європи". Документ визначив чотири регіональні пріоритетні завдання (РПЗ) щодо зниження тягаря екологічно зумовлених захворювань у дітей для 53 країн Європейського регіону.

І. Забезпечення належних санітарних умов та безпечної води для дітей у школах та інших закладах

II. Попередження травм на дорогах та організація фізичної активності.

III. Чисте повітря на вулиці та у приміщеннях.

IV. Спрямування зусиль на звільнення довкілля від хімікатів [5]

Під час Будапештської конференції кожен міністр взяв зобов'язання розробити регіональний план з покращання ситуації в усіх чотирьох напрямках та надіслати звіт про діяльність та проекти, які здійснюються для покращання умов життя дітей, а саме: законодавство, пропаганда здорового способу життя, підвищення рівня знань, удосконалення системи надаваних послуг, спостереження за ризиками, спричине- ними факторами довкілля [5].

Так, усі чотири Регіональні пріоритетні завдання (РПЗ), визначені 2004 року у Будапешті на Четвертій конференції на рівні міністрів 3 довкілля та охорони здоров'я "Майбутне для наших дітей", були підтверджені 2010 року у ході П'ятої Міністерської конференції з довкілля і здоров'я "Захищаючи здоров'я дітей у довкіллі, яке змінюється", проведеної 10-12 березня 2010 року у м. Парма (Італія) [10].

У ході Пармської міністерської конференції було розглянуто основні шляхи вирішення найважливіших проблем сучасності у сфері навколишнього середовища і здоров'я, а також наголошено, що захист прав та інтересів підростаючого покоління світова спільнота має виконувати для дітей та разом з дітьми [10].

3 урахуванням усіх рекомендацій ВООЗ разом з Європейською комісією з охорони довкілля було розроблено Глобальний План дій для здоров'я дітей і довкілля (2010-2015), який має на меті створення безпечного, здорового і чистого навколишнього середовища, в якому діти могли б зростати і розвиватися у доброму здоров'ї та сприяти економічному і соціальному розвитку суспільства. Також, враховуючи нагальні потреби з захисту здоров'я дітей та їхнього довкілля, ВООЗ розробила низку документів.

口 Глобальна стратегія у сфері раціону харчування, фізичної активності та здоров'я (2004).

口 Європейський план дій 3 довкілля і здоров'я людей на 2004-2010 роки (2004).

- Європейська стратегія "Здоров'я та розвиток дітей та підлітків"(2005).

口 Рамкова конвенція В0О3 з боротьби проти тютюну (2005).

- Стратегія, підготовлена у 
рамках програми "Чисте повітря в Європі" (2005).

口 Документ "Попередження травматизму в Європейському регіоні ВОО3" (2005)

口 Документ "Сприяння фізичній активності для здоров'я платформа для дій в Європейському регіоні ВООЗ" (2006).

$\square$ Європейський план дій ВООЗ з політики у сфері харчових продуктів та харчування на 20072012 роки.

口 Глобальна стратегія з профілактики та боротьби 3 неінфекційними захворюваннями на 2008-2013 роки.

口 Глобальна стратегія скорочення шкідливого вживання алкоголю (2010).

口 Рамочна програма дій "Захист здоров'я в умовах впливу зміни клімату на довкілля" (2010).

口 Документ "Попередження дитячого травматизму" (2011).

- План дій з реалізації Європейської стратегії профілактики та боротьби з неінфекційними захворюваннями на 2012-2016 роки.

口 "Європейська доповідь про запобігання жорстокого поводження $з$ дітьми" (2013) та багато інших документів.

Спираючись на досвід реалізації попередніх стратегій, зокрема "Здоров'я для всіх", ВООЗ розробило нову європейську стратегію з охорони здоров'я "Основи політики та стратегія Здоров'я-2020". Основи європейської політики на підтримку дій усієї держави і суспільства в інтересах здоров'я і благополуччя ставить ряд перспективних і сміливих завдань у справі охорони здоров'я людей. Ці основи у вересні 2012 року були прийняті усіма 53 державамичленами Європейського регіону ВООЗ у найважливіший момент. Так, 2015 рік - контрольний термін для досягнення Цілей розвитку тисячоліття (ЦРТ), і нова політика допоможе визначити місце охорони здоров'я у подальшому комплексі глобальних цілей відповідно до нової Європейської політики "Здоров'я-2020".

Україна, як і більшість країн міжнародного співтовариства, визнала, що діти та молодь $€$ одним з пріоритетів державної політики. Від рівня їхнього здоров'я великою мірою залежить формування трудового та інтелектуального потенціалу України [11]. Тому за увесь період незалежності в Україні було розроблено, затверджено та впроваджено багато державних програм, спрямованих на вирішення ключових питань нашого часу у сфері довкілля та здоров'я, зокрема Національна програма "Діти України" на 1996-2000 роки, Міжгалузева комплексна програма "Здоров'я нації" на 2002-2011 роки, Державна програма "Дитяча онкологія" на 2006-2010 роки, Державна цільова програма "Молодь України" на 2009-2015 роки, Державна програма "Репродуктивне здоров'я нації до 2015 року", Загальнодержавна програма "Національний план дій щодо реалізації Конвенції ООН про права дитини" на період до 2016 року, Національний проект "Нове життя - Нова якість охорони материнства та дитинства" на 20112013 роки.

Стратегічно важливим пріоритетним завданням нашої держави у галузі охорони здоров'я $€$ збереження життя та здоров'я дітей і підлітків. Так, у липні 2007 року Кабінет Міністрів України затвердив Концепцію Державної програми "Здорова дитина" на 2008-2017 роки відповідно до Європейської стратегії ВООЗ "Здоров'я та розвиток дітей і підлітків" [8]

Україна бере активну участь у реалізації багатьох європейських стратегій, які мають на меті створення безпечного, здорового і чистого навколишнього середовища, в якому діти могли б зростати і розвиватися у доброму здоров'ї та сприяти економічному і соціальному розвиткові суспільства.

Погіршення стану дітей в Україні пов'язане 3 різними причинами, серед яких соціально-економічна нестабільність суспільства, екологічні проблеми, недостатня матеріально-технічна база та недосконала структура системи охорони здоров'я, відсутність санітарно-гігієнічних навичок у дітей та підлітків, відсутність у них пріоритетної спрямованості на здоров'я і мотивації до здорового способу життя. Крім того, негативний вплив на здоров'я підростаючого покоління підвищує навантаження і нервовопсихічну напругу, невідповідність системи фізичного виховання сучасним особливостям фізичного розвитку та динаміки фізичної підготовленості дітей, а також нераціональне харчування [11].

Так, за заходами Міжгалузевої комплексної програми "Здоров'я нації" на 2002-2011 роки фахівцями НАМН України було розроблено шляхи вирішення медико-соціальних проблем формування здоров'я дітей і підлітків:

口 розробка та впровадження державної політики щодо збереження та зміцнення здоров'я дітей і підлітків;

口 створення умов для відновлення потенціалу здоров'я підростаючого покоління країни;

口 забезпечення дітей і підлітків доступною, необхідною медич- ною допомогою;

$\square$ створення системи моніторингу здоров'я школярів з урахуванням впливу на його формування факторів довкілля;

$\square$ забезпечення умов для свідомого і бережливого ставлення школярів до власного здоров'я;

$\square$ посилення заходів первинної та вторинної профілактики найбільш поширених захворювань;

$\square$ удосконалення диспансерного спостереження дітей усіх вікових груп;

$\square$ забезпечення наукової бази впровадження у медичне забезпечення дітей і підлітків відповідно до стандартів світового рівня;

$\square$ створення єдиної інформаційної системи медичної, педагогічної та психологічної інформації щодо формування, збереження та укріпленню здоров'я дітей з урахуванням впливу факторів довкілля [11].

3 урахуванням положень стратегії Всесвітньої організації охорони здоров'я "Здоров'я для всіх", рекомендацій та ключових засад інших програмних і стратегічних документів, включаючи Талліннську хартію "Системи охорони здоров'я для здоров'я і добробуту", Європейську політику в охороні здоров'я "Здоров'я2020", у грудні 2013 року до Верховної Ради України подано проект Закону про затвердження Загальнодержавної програми "Здоров'я - 2020: український вимір" [12].

Проект Загальнодержавної програми "Здоров'я-2020: український вимір" спрямовано на реалізацію стратегічних пріоритетів України у сфері охорони здоров'я щодо профілактики хронічних неінфекційних захворювань, мінімізації впливу факторів ризику їхнього розвитку на основі міжсекторального підходу, створення сприятливого для здоров'я середовища, формування відповідального ставлення громадян до особистого здоров'я та мотивації населення до здорового способу життя, а також оптимізації організації і фінансування медичної галузі зі створенням дієвої системи охорони громадського здоров'я, зорієнтованої на пріоритетний розвиток первинної медичної допомоги, сімейної медицини, спроможної забезпечити медичні потреби населення на рівні чинних стандартів, у т.ч. за найбільш значущими у соціально-економічному та медико-демографічному плані хронічними неінфекційними захворюваннями [3, 12].

Сучасні тенденції здоров'я населення світу свідчать про прогресуюче поширення НІЗ та фак- 
торів ризику їх розвитку, значні медико-соціальні втрати та економічні збитки. Тому ВООЗ розробила Глобальний план дій щодо попередження та контролю НІЗ на 2013-2020 роки, який передбачає вплив на усі вікові групи; залучення громадськості та кожної людини; стратегії, засновані на доказах; всеохоплююче покриття витрат на медичні цілі; запобігання конфлікту інтересів; гарантування прав людини; забезпечення рівного доступу до медичних та профілактичних послуг; національні заходи та медичну співпрацю; міжсекторальну взаємодію [4].

Зважаючи на захворюваність та смертність через найбільш небезпечні НІЗ в Україні, особливо на незадовільні показники дитячого здоров'я, що значно випереджають аналогічні показники в інших європейських країнах, органи влади налаштовані на втілення нових підходів до їх покращання, зокрема впровадження нової програми - проекту Національного плану з імплементації та реалізації засад європейської стратегії "Здоров'я-2020: основи Європейської політики на підтримку дій держави і суспільства в інтересах здоров'я і благополуччя" щодо неінфекційних захворювань на період до 2020 року. Цей проект нової програми є інструментом для досягнення найвищої мети - збереження та зміцнення здоров'я нації.

Участь України у програмах $\mathrm{OOH}$ з навколишнього середовища (ЮНЕП) та програмах ВООЗ $з$ охорони здоров'я сприяла подальшому підвищенню міжнародного іміджу України, забезпеченню її національних інтересів, широкому інформуванню світового співтовариства про хід змін, що відбуваються у сфері охорони здоров'я, подальшому вдосконаленню нормативно-правової бази з забезпечення реалізації державної політики у напрямку з охорони довкілля, збереження життя та здоров'я дітей і підлітків.

Кожна дитина повинна мати можливість жити здоровим і повноцінним життям. Для реалізації цієї можливості країни Європейського регіонального бюро ВООЗ прийняли нову стратегію "Інвестуючи у майбутнє дітей: Європейська стратегія охорони здоров'я дітей та підлітків, 20152020 рр.". Стратегія рекомендує використання підходу з урахуванням усіх етапів життя, заснованого на визнанні того, що здоров'я i захворюваність у дорослих визначаються станом здоров'я та досвідом у попередніх етапах життя. Також керівні принципи стратегії передбачають викори- стання підходу, що ґрунтується на фактичних даних, стимулюванні найсильніших партнерств і міжсекторального співробітництва. Європейська стратегія орієнтована на розвиток і захист прав та інтересів підростаючого покоління, на завдання, які світова спільнота має виконувати для дітей та разом з дітьми [9].

Європейська стратегія охорони здоров'я дітей та підлітків наголошує на тому, що інвестиції у розвиток дітей та підлітків не тільки призведуть до поліпшення показників здоров'я, але й принесуть користь в економічній і соціальній сферах [9].

Перспективи подальшого розвитку державної політики у сфері охорони довкілля і здоров'я дітей полягають у вивченні міжнародного досвіду, адаптації та імплементації законодавчих і науково-дослідних матеріалів ВООЗ та розробці відповідних нормативно-правових актів з охорони довкілля і здоров'я дітей в Україні.

\section{Висновки}

Охорона здоров'я дітей та довкілля - це ключова передумова для забезпечення сталого розвитку у країнах світу. Діти повинні мати можливість рости і жити у здоровому середовищі. Наслідки впливу несприятливих факторів довкілля на здоров'я людини, особливо дітей, можуть бути дуже тривалими, поширюючись на багато поколінь. Вони вимагають повної оцінки і прийняття адекватних заходів для зведення до мінімуму ризиків для здоров'я. Завдяки процесу створення Національних планів дій щодо НІ3 та гігієни довкілля виникла взаємодія між сферами охорони здоров'я, охорони навколишнього середовища та іншими значущими секторами економіки, а також з'явився новий підхід до спільної роботи над проблемами здоров'я людей і довкілля $[7,9,10]$.

Процеси глобалізації, демографічні, соціальні, економічні та екологічні зміни кидають виклик усім країнам світу. Останніми десятиліттями у багатьох країнах світу при виконанні профілактичних програм були отримані переконливі результати, які наочно підтвердили необхідність широкомасштабного здійснення комплексних профілактичних заходів на популяційному рівні, що є найбільш ефективною стратегією на довгострокову перспективу. Саме профілактика, реалізована у рамках національних стратегій на основі міжсекторального підходу, є реальним механізмом вирішення глобальних проблем у сфері збереження і зміцнення здоров'я [3, 4, 11].

\section{ЛІТЕРАТУРА}

1. A Strategy to Prevent Chronic Disease in Europe. A Focus on Public Health Action. The CINDI vision / WHO. - Copenhagen, 2004. - $42 \mathrm{p}$.

2. HEALTH 21 - Health for all in the 21-st Century / WHO. - Copenhagen, 1998. - $36 \mathrm{p}$.

3. Health 2020. A European Policy Framework and Strategy for the 21st Century / WHO. - Copenhagen, 2013. - $190 \mathrm{p}$.

4. Global Strategy for the Prevention and Control of Noncommunicable Diseases. Fifty-third World Health Assembly. - 2000. - Available at: http://apps.who.int/gb/archive/pdf_files/WHA53/ea14.pdf?ua=1

5. Fourth Ministerial Conference on Environment and Health, Budapest, Hungary, 23-25 June 2004. Declaration (EUR/04/5046267/6). - Available at: http://www.euro. who.int/_data/assets/pdf_file/ $0008 / 885 \overline{7} 7 /$ E83335. pdf?ua $=1$

6 . Health and the Millennium Development Goals / WHO. - Geneva. $-2005 .-84 \mathrm{p}$.

7. Europe's Environment. The Fourth Assessment. Chapter 2. Environment and Health and the Quality of Life / European Environment Agency. - Copenhagen, 2007. - $92 \mathrm{p}$.

8. Проект Розпорядження Кабінету Міністрів України "Про схвалення Концепції Державної програми "Здорова дитина" на 20082017 рр. [Електронний ресурс]. Режим доступу: http://healthua.com/articles/2030.html

9. Investing in Children: the European Child and Adolescent Health Strategy 2015-2020 / WHO. - Copenhagen, 2014. - $23 \mathrm{p}$.

10. Fifth Ministerial Conference on Environment and Health "Protecting Children's Health in a Changing Environment", Parma, Italy, 10-12 March 2010. - Declaration (EUR/55934/5.1 Rev. 2). Available at : http://www. euro.who.int/ data/assets/pdf file $/ 0011 / 78608 /$ E93618.pdf?ua $=1$

11. Про затвердження Міжгалузевої комплексної програми "Здоров'я нації" на 2002-2011роки : Постанова Кабінету Міністрів України від 10.01.2002 № 14 [Електронний ресурс]. - Режим доступу: http://zakon4.rada.gov.ua/laws/ show/14-2002-\%D0\%BF.

12. Проект Закону України "Про затвердження Загальнодержавної програми "Здоров'я-2020: український вимір"[Електронний ресурс]. - Режим доступу: http://triton.moz.gov.ua/ua/portal/Pro 20120316 1.html

13. Про Загальнодержавну програму "Національний план дій щодо реалізації Конвенції ООН про права дитини" на період до 2016 року : Закон України від 05.03.2009 № 1065-VI [Електронний ресурс]. - Режим доступу: http://zakon4. rada.gov.ua/laws/ show/1065-17 REFERENCES

1. WHO A Strategy to Prevent Chronic Disease in Europe. A Focus on Public Health Action. The CINDI 
vision. Copenhagen ; 2004 : 42 p.

2. WHO HEALTH 21 - Health for all in the 21st Century. Copenhagen : $1998: 36 \mathrm{p}$.

3. WHO Health 2020. A European Policy Framework and Strategy for the 21st Century. Copenhagen ; 2013 : $190 \mathrm{p}$.

4. Global Strategy for the Prevention and Control of Noncommunicable Diseases. Fifty-third World Health Assembly. 2000. Available at: http://apps.who.int/gb/archive/pdf files/WHA53/ea14.pdf?ua=1

5. Fourth Ministerial Conference on Environment and Health, Budapest, Hungary, 23-25 June 2004. Declaration (EUR/04/5046267/6). Available at: http://www.euro.who. int/ data/assets/pdf file/0008/ 8857̄7/E83335.pdf?ua $=\overline{1}$

6 . WHO Health and the Millennium Development Goals. Geneva ; 2005: 84 p.

7. European Environment Agency Europe's Environment. The Fourth Assessment. Chapter 2. Environment and Health and the Quality of Life. Copenhagen ; 2007: 92 p.

8. Proekt Rozporiadzhennia Kabinetu Ministriv Ukrainy "Pro skhvalennia Kontseptsii Derzhavnoi prohramy "Zdorova dytyna" na 2008-2017 rr. [Decree Project of the Cabinet of Ministers of Ukraine "On the Approval of the Healthy Child National Program Conception for 2008-2017]. Available at : http://triton.moz. gov.ua/ua/portal/dn_20070713 0. html\#1

9. WHO Investing in Children: the European Child and Adolescent Health Strategy 2015-2020. Copenhagen ; $2014: 23 \mathrm{p}$

10. Fifth Ministerial Conference on Environment and Health "Protecting Children's Health in a Changing Environment", Parma, Italy, 10-12 March 2010. - Declaration (EUR/55934/ 5.1 Rev. 2). Available at : http://www. euro.who.int/_data/assets/pdf_file $/ 0011 / 78608 /$ E93618.pdf?ua $=1$

11. Pro zatverdzhennia Mizhhaluzevoi kompleksnoi prohramy "Zdorovia natsii" na 2002-2011roky : Postanova Kabinetu Ministriv Ukrainy [On the Approval of the Health of Nation Interbranches' Complex Program]. Avaliable at : http://zakon4.rada.gov.ua/laws/show/14-2002$\% \mathrm{DO} \% \mathrm{BF}$

12. Proekt Zakonu Ukrainy "Pro zatverdzhennia Zahalnoderzhavnoi prohramy "Zdorovia - 2020: ukrayinskyi vymir" [Law Project of Ukraine "On the Approval of the National Program "Health - 2020: Ukrainian Measuring]. Avaliable at : http://triton.moz.gov.ua/ua/portal/Pro 20120316 1.html

13. Pro Zahalnoderzhavnu prohramu "Natsionalnyi plan dii shchodo realizatsii Konventsii OON pro prava dytyny" na period do 2016 roku [On the National Program "National Plan for the Realization of the UN Conception on the Child's Rights" for the Period till 2016]: Zakon Ukrainy vid 05.03.2009 № 1065-VI. Avaliable at: http://zakon4.rada.gov.ua/laws/ show/1065-17

Надійшла до редакції 02.08.2015

FEATURES OF THE MORBIDITY FORMATION AMONG PRE-SCHOOL AGE CHILDREN IN DEPENDENCE OF ECOLOGICAL CONDITIONS II THE PLACES OF RESIDENCE Rudnytska O.P., Berdnyk O.v.

\section{ОСОБЛИВОСТ ФОРМУВАННЯ ЗАХВОРЮВАНОСТ ДІТЕЙ ДОШКІЛЬНОГО ВІКУ ЗАЛЕЖНО ВІД ЕКОЛОГГЧНИХ УМОВ У МІСЦЯХ ПРОЖИВАННЯ}

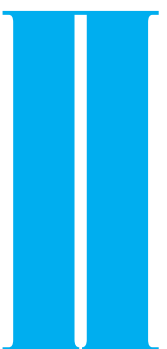

РУДНИЦЬКА О.П., БЕРДНИК О.В. ДУ "Інститут громадського здоров'я ім. О.М. Марзєєва НАМН України", м. Київ

УДК 614. 7: 613: 312.6 (477) ротягом останніх десятиліть у світі спостерігається подальше порушення екологічної рівноваги, що призводить до деградації не тільки середовища, а і здоров'я людей. Згідно з даними ВООЗ понад $30 \%$ щорічних смертей у світі пов'язані 3 впливом навколишнього середовища [1]. У світовій науковій літературі накопичено значний фактичний матеріал щодо негативного впливу довкілля. Bce це зумовило формування поняття "екологічне громадське здоров'я", яке характеризує оновлене громадське здоров'я і зв'язок фізичного, психічного та соціального благополуччя з екологічними, соціально-економічними, культурними, політичними та

\section{ОСОБЕННОСТИ ФОРМИРОВАНИЯ ЗАБОЛЕВАЕМОСТИ ДЕТЕЙ} ДОШКОЛЬНОГО ВОЗРАСТА В ЗАВИСИМОСТИ ОТ ЭКОЛОГИЧЕСКИХ УСЛОВИЙ В МЕСТАХ ПРОЖИВАНИЯ Рудницкая О.П., Бердник О.В.

Цель: изучение особенностей формирования уровня заболеваемости детей старшего дошкольного возраста, проживающих в разных с экологической точки зрения микрорайонах.

Объекты и методы исследований. Наблюдением были охвачены дети 5-6 лет, которые проживают и посещают дошкольные учреждения г. Киева, расположенные в разных экологических условиях: возле крупных автомагистралей, около промпредприятий и в относительно чистом микрорайоне. Исходящие материалы были получены путем выкопировки данных из первичной медицинской документации в дошкольных учреждениях, а также письменного опроса родителей о развитии и состоянии здоровья ребенка на ранних этапах онтогенеза. Оценка резистентности организма проводилась на основе определения кратности и длительности острых респираторных инфекций.

Результаты. Полученные данные свидетельствуют, что формирование заболеваемости существенно зависит от экологических условий в местах проживания. Наиболее интенсивно формирование заболеваемости происходит на территориях, расположенных поблизости от крупных автомагистралей: уровень заболеваемости детей в этих дошкольных учреждениях превышает аналогичный показатель в микрорайоне около промпредприятий в 1,76 раза, в относительно чистом микрорайоне - в 1,91 раза. Наивысший удельный вес детей, часто и длительно болеющих и слабо резистентных к острым респираторным инфекциям, также выявлен в дошкольных учреждениях, расположенных у автомагистралей. Поэтому на сегодняшний день необходимо возобновить проведение предупредительного санитарного надзора относительно размещения дошкольных учреждений и контроля окружающей среды, а именно: атмосферного воздуха в местах их размещения.

Ключевые слова: дети дошкольного возраста, заболеваемость, резистентность организма, экологические условия.

๑) Рудницька О.П., Бердник О.В. СТАТТЯ, 2016.

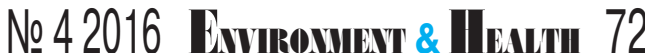

